\title{
Ordovician sponges from west-central and east-central Alaska and western Yukon Territory, Canada
}

\author{
J. KEITH RIGBY, ROBERT B. BLODGETT \& BROOKS B. BRITT
}

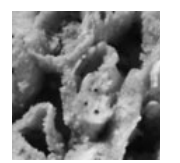

\begin{abstract}
Moderate collections of fossil sponges have been recovered over a several-year period from a few scattered localities in west-central and east-central Alaska, and from westernmost Yukon Territory of Canada. Two fragments of the demosponge agelasiid cliefdenellid, Cliefdenella alaskaensis Stock, 1981, and mostly small unidentifiable additional fragments were recovered from a limestone debris flow bed in the White Mountain area, McGrath A-4 Quadrangle in west-central Alaska. Fragments of the agelasiid actinomorph girtyocoeliids Girtyocoeliana epiporata (Rigby \& Potter, 1986) and Girtyocoelia minima n. sp., plus a specimen of the vaceletid colospongiid Corymbospongia amplia Rigby, Karl, Blodgett \& Baichtal, 2005, were collected from probable Ashgillian age beds in the Livengood B-5 Quadrangle in east-central Alaska. A more extensive suite of corymbospongiids, including Corymbospongia betella Rigby, Potter \& Blodgett, 1988, C. mica Rigby \& Potter, 1986, and C.(?) perforata Rigby \& Potter, 1986, along with the vaceletiid colospongiids Pseudo-imperatoria minima? (Rigby \& Potter, 1986), and Pseudoimperatoria media (Rigby \& Potter, 1986), and with the heteractinid Nucha naucum? Pickett \& Jell, 1983, were recovered from uppermost part of the Jones Ridge Limestone (Ashgillian), on the south flank of Jones Ridge, in the Sheep Mountain Quadrangle, in westernmost Yukon Territory, Canada. The fossil sponges from the McGrath A-4 and Livengood B-5 quadrangles were recovered from attached Siberian terranes, and those from the Sheep Mountain Quadrangle were recovered from an allochthonous Laurentian terrane in the Yukon Territory. Key words: Porifera, sponge, Ordovician, Alaska, Yukon Territory, Jones Ridge Limestone.
\end{abstract}

RigBY, J.K., BLODGETT, R.B. \& BRITT, B.B. 2008. Ordovician sponges from west-central and east-central Alaska and western Yukon Territory, Canada. Bulletin of Geosciences 83(2), 153-168 (4 figures). Czech Geological Survey, Prague. ISSN 1214-1119. Manuscript received March 7, 2008; accepted in revised form May 20, 2008; issued June 30, 2008.

J. Keith Rigby \& Brooks B. Britt, Room 165, Earth Science Museum, Department of Geological Sciences, Brigham Young University, Provo,Utah 84602-4606; rigbyjkeith@gmail.com, brooks.britt@gmail.com • Robert B. Blodgett, U.S. Geological Survey - Contractor, 4200 University Drive, Anchorage, Alaska; rblodgett@ usgs.gov

Several species of Late Ordovician hypercalcified demosponges have been collected as parts of major paleontographic studies over the past few years from localities in west-central and east-central Alaska and westernmost Yukon Territory in Canada (Figs 1,2). These sponges are the objects of the present study.

As noted by Rigby et al. (1988), the Early Paleozoic record of sphinctozoan sponges is essentially a circum-Pacific record. Sphinctozoan sponges are seemingly abundant in Ordovician-Devonian carbonate rocks of Alaska (Rigby \& Blodgett 1983; Rigby et al. 1988, 1994, 2005, 2008). Their Alaskan occurrences are primarily in the accreted terranes (i.e., Farewell, Livengood, White Mountains, and Alexander terranes), which make up the bulk of the state, but they are also found in Ashgillian (late Late Ordovician) strata of the uppermost Jones Ridge Limestone, situated along the Alaska-Yukon border in autochthonous rocks belonging to Laurentia. Recent paleobiogeographic studies of Early Paleozoic rocks of Alaska's accreted terranes indicate that many of them ap- pear to have a Siberian origin (Blodgett \& Boucot 1999, Blodgett et al. 2002, Dumoulin et al. 2002).

The late Precambrian-Mesozoic stratigraphic succession from the Jones Ridge area and adjoining regions of east-central Alaska and adjacent Yukon Territory is the most complete stratigraphic succession of rocks of these ages known from Alaska. As noted above, most of Alaska consists of various accreted terranes which coalesced in the late Mesozoic, but the Jones Ridge area is part of the westernmost exposure of autocthonous North American stratigraphy in Alaska, and has undergone virtually no displacement relative to the North American craton since Neoproterozoic time.

\section{Localities}

Three separate Early Paleozoic sphinctozoan sponge localities (Figs 1,2), two in interior Alaska and another in $\mathrm{Yu}-$ kon Territory, approximately $1.0 \mathrm{~km}$ east of the 


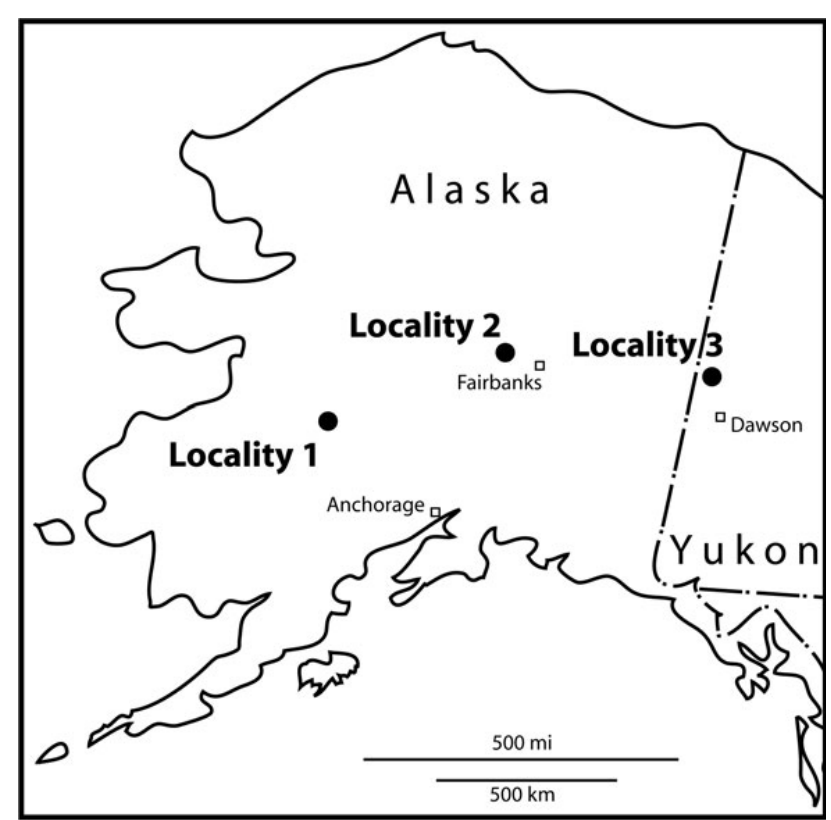

Figure 1. Generalized map of part of Alaska and Yukon Territory showing the relative positions of sponge Localities 1-3. Locality 1 is in White Mountain, in the McGrath A-4 Quadrangle; Locality 2 is in the White Mountains, in the Livengood B-5 Quadrangle, both in central Alaska; and Locality 3, in the Jones Ridge area, is in the Sheep Mountain Quadrangle, Yukon Territory, Canada.

Alaska-Yukon border, yielded the fossil material described here. Geographic and stratigraphic details of each of the localities are presented below.

Locality 1. 85RB28, Late Ordovician (probably Ashgillian), Lat. $62^{\circ} 10.3^{\prime}$ N., Long. $154^{\circ} 53.6^{\prime} \mathrm{W}$., or NW $1 \frac{1}{4}, \mathrm{SE}^{1 / 4}$, $\mathrm{SE}^{1 / 4}$, NE $1 / 4$, sec. 14, T. 24 N., R 31 W., McGrath A-4 Quadrangle, west-central Alaska, on the crest of an east-west trending spur ridge on the south side of White Mountain, elevation 2,200 ft. (Fig. 2A). Sponge specimens documented here were collected by R.B. Blodgett, June 1985. This collection includes 3 fragments of Cliefdenella alaskensis Stock, 1981, and 4 unidentifiable sphinctozoans with "spheroidal" chambers, without pores or fibers evident in either interior or exterior elements. The collection also includes additional mostly small unidentifiable rock fragments.

Some Ordovician sponges were previously described from the White Mountain area by Rigby et al. (1988; see Fig. 2A therein for the locality location). Those sponges were collected over a stratigraphic interval estimated to be on the order of 250-300 $\mathrm{m}$ in thickness and constituted of interbedded limestone and siltstone-shale. This interval forms the u01 (limestone and argillite) unit of Gilbert (1981). Many, if not most, of the limestone beds in this interval were inferred to have been "deposited below storm-wave base by debris flows and turbidity currents at a site on the foreslope seaward of a shelf margin or outboard of the break in slope on a distantly steepened ramp" (Rigby et al. 1988, p. 735). Fossils from this interval range in age from Middle Ordovician (Llandeilian) to Late Ordovician (Ashgillian).

Collection $85 \mathrm{RB} 28$ is from a limestone debris flow, 8-9 ft. (2.4-2.7 m) thick, that consists of lime rudstone and grainstone, and contains rip-up clasts and an abundant silicified megafauna, mostly brachiopods and crinoid columnals. The age of these beds is considered to be Ordovician (probably Ashgillian) based on the presence of the Cliefdenella, as well as the general aspect of the silicified brachiopods recovered here.

The White Mountain area is part of the Nixon Fork terrane (Patton 1978), which was later reduced to the status of a subterrane (along with the allied Dillinger and Mystic subterranes) as part of the larger Farewell terrane (Decker et al. 1994). As noted above, the Farewell terrane is now recognized to be of Siberian origin based on its Paleozoic fossil biota (Blodgett \& Boucot 1999, Blodgett et al. 2002).

Locality 2. 87APr108B (=87ABd76 of Blodgett), Ashgillian, Lat. $65^{\circ} 25.85^{\prime}$ N., Long. $149^{\circ} 04.03^{\prime}$ W., or SW $1 \frac{1}{4}$, NW $1 \frac{1}{4}$, SE $1 \frac{1}{4}$, sec. 18, T. 7 N., R. 7 W., Livengood B-5 Quadrangle, east-central Alaska (Fig. 2B). The sample consisted of a limestone cobble about 5 inches long and 3 inches in diameter. It was collected by George Plafker of the U.S. Geological Survey in 1987, from a conglomerate consisting of poorly sorted cobble- and boulder-sized clasts of limestone, gabbro, red jasper, ultramafic rocks, and reddish-brown chert. The cobble was subsequently etched, and the residue contained silicified sponges, crinoid ossicles, corals, and shell fragments. Age of the conglomerate is probably Middle Ordovician-Silurian, based on field relationships and the presence of halysitid tabulate corals found in this and similar nearby clasts collected by R.B. Blodgett in April 1987.

Sponge specimens, included in the collection from the cobble, include: Girtyocoeliana epiporata (Rigby \& Potter, 1986), 3 fragments; Girtyocoelia minima n. sp., 1 fragment; and Corymbospongia amplia Rigby, Karl, Blodgett \& Baichtal, 2005, 1 fragment.

The age of the limestone clast yielding these sponges is considered to be Ashgillian, as the species Girtyocoeliana epiporata (Rigby \& Potter, 1986) was previously reported from several localities of Ashgillian age in the Klamath Mountains of northern California. Conodonts recovered from separate nearby collections of limestone conglomerate clasts (87ABd75, 75A, and 75B of Blodgett) yielded conodonts indicative of a Middle or Late Ordovician age (Weber et al. 1994, p. 19).

The exposures that contain the conglomeratic beds at Locality 2 were placed questionably in the Dq unit (Quail unit) by Weber et al. (1992), and unquestionably in this unit by Weber et al. (1994). One of us (Blodgett) now dis- 


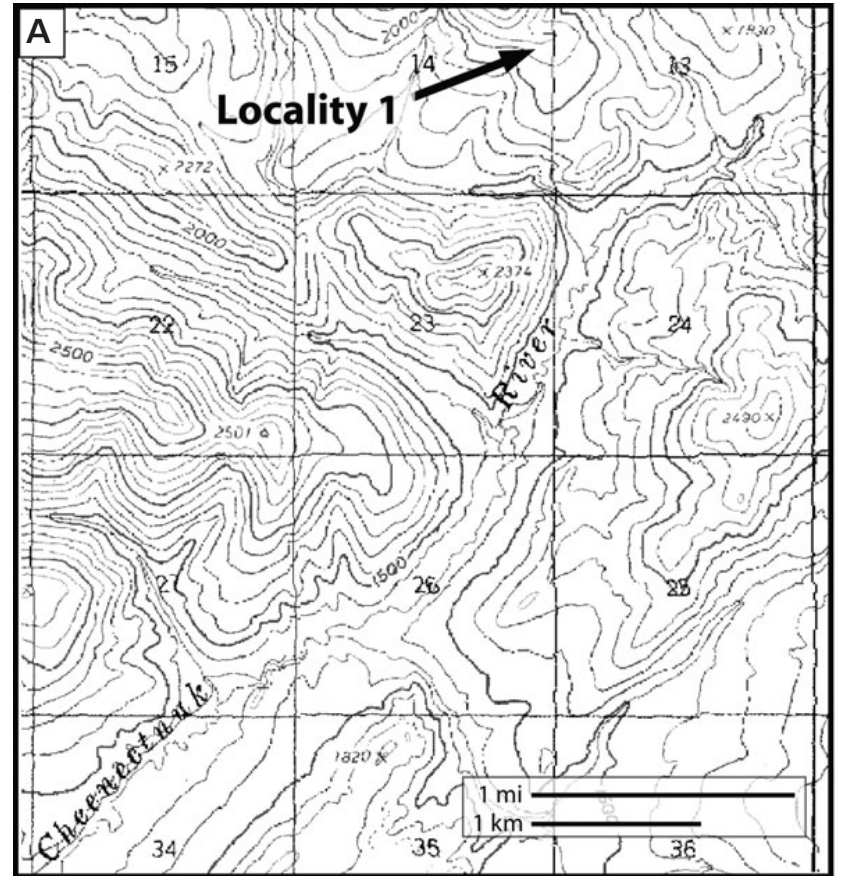

Figure 2. Topographic maps of localities in Alaska and western Canada from which the sponges documented here were collected. $\bullet$ A - Locality 1 , Blodgett Locality 85RB28, in the White Mountain area, McGrath A-4 Quadrangle, west-central Alaska. • B - Locality 2, White Mountains area, Plafker Locality 87APr108B, Livengood B-5 Quadrangle, east-central Alaska. • C - Locality 3, Jones Ridge, Locality Yx-51-70, approximately $0.63 \mathrm{mi}$. (1.0 km) east of the Alaska-Canada border in the Sheep Mountain Quadrangle, Yukon Territory, Canada.

agrees with this unit assignment, as the rocks here at Locality 2 are quite unlike conglomerates of the Late Devonian Quail unit typically exposed to the west in the Livengood B-6 Quadrangle. He has concluded that the rocks at Locality 2 are somewhat older that the Dq unit and belong to a new unit, which could be established with further detailed mapping of the north flank of Cascaden Ridge. All the rocks referred to here belong in the Livengood terrane of Churkin et al. (1982).

Locality 3. Yx-51-70. Ashgillian, uppermost Jones Ridge Limestone, upper member; the fossil locality is on the southeast flank of Jones Ridge, approximately $0.63 \mathrm{mi} .(1.0 \mathrm{~km})$ east of the Alaska-Canada border, at Lat. $60^{\circ} 06.7^{\circ} \mathrm{N}$., Long. $140^{\circ}$ 58.7' W., Sheep Mountain Quadrangle, in Yukon Territory, Canada (Fig. 2C). The silicified sphinctozoan sponges, documented here, were collected in limestone blocks, in 1970, by A.R. Ormiston, and were later recovered after acidization of the blocks. Silicified brachiopods from this horizon indicate an Ashgillian (Late Ordovician) age for the beds (Ross \& Dutro 1966; Potter et al. 1980, 1988).

Sponges have been previously reported from the locality by Rigby et al. (1988; see Fig. 2B therein for the locality location). The current collection includes specimens of: Corymbospongia betella Rigby, Potter \& Blodgett, 1988,
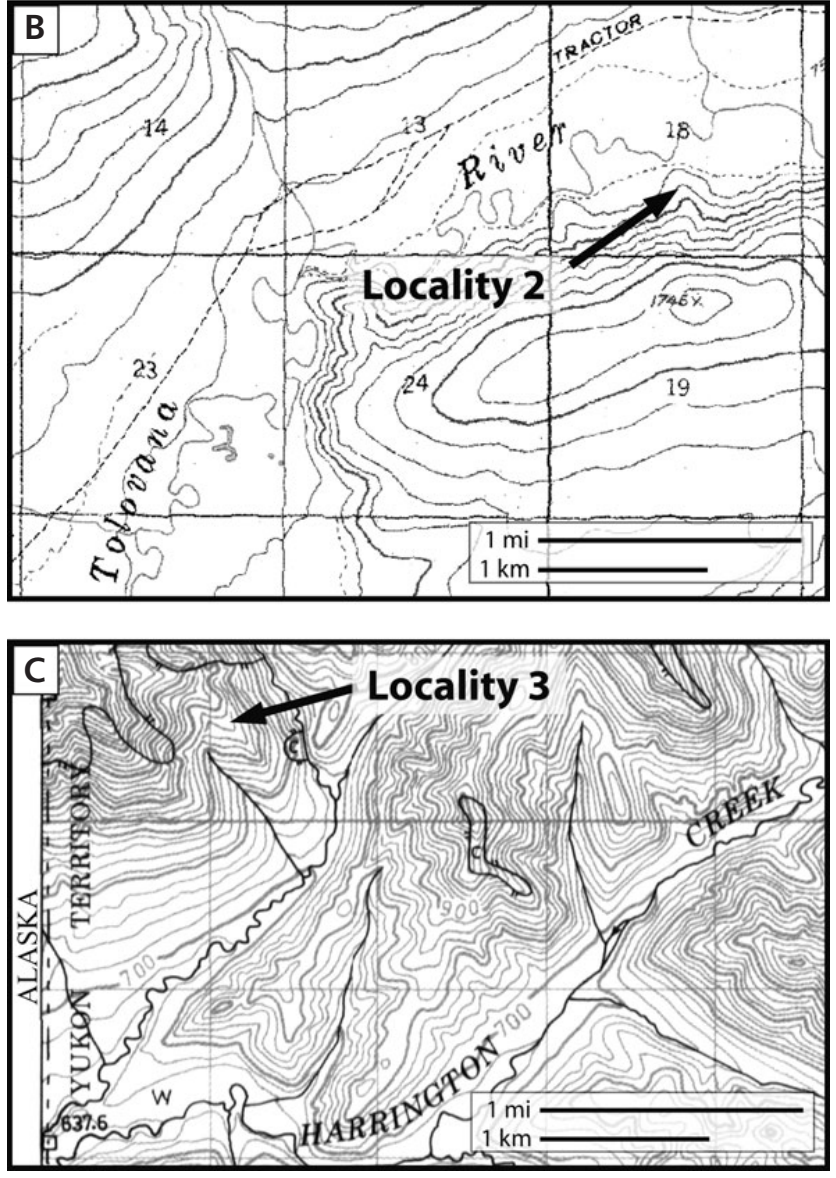

C. mica Rigby \& Potter, 1986, C.(?) perforata Rigby \& Potter, 1986, Pseudoimperatoria minima? (Rigby \& Potter, 1986), Pseudoimperatoria media (Rigby \& Potter, 1986), and Nucha naucum? Pickett \& Jell, 1983.

\section{Systematic paleontology}

We follow the classification of hypercalcified chambered fossil sponges used by Finks \& Rigby (2004b, pp. 585-764) in the Treatise on Invertebrate Paleontology, revised. However, as a result of the polyphyletic nature of these chambered sponges (Hooper \& Van Soest 2002, Reitner \& Keupp 1991, Rigby \& Senowbari-Daryan 1996, etc.), their preservation problems, and gaps in their geologic records, definitive classifications of some fossil sponges at class and order levels are still uncertain.

Class Demospongea Sollas, 1875

Subclass Ceractinomorpha Lévi, 1953

Order Agelasida Verrill, 1907

Family Girtyocoeliidae Finks \& Rigby, 2004b

Diagnosis. - "Spheroidal chambers; exowall generally imperforate, with well-developed exauli, that may contain 
internal cribribulla, in equatorial ring; cloaca present except in juveniles (protocysts), with endopores often concentrated in a ring; filling structures sparse to absent, but vesicles or trabeculae may occur" (Finks \& Rigby 2004b, p. 658).

\section{Genus Girtyocoelia Cossmann, 1909}

Type species. - Heterocoelia beedei Girty, 1908, p. 284. (See Cossmann, 1909, p. 67.

Diagnosis. - "Spherical segments, or spheroidal when in contact, arranged in subparallel, branching, occasionally anastomosing, linear series; segments in each series connected by continuous, narrow, central tube or cloaca that is frequently visible externally between segments and protrudes beyond last segment (prosiphonate); juveniles (protocysts) adnate on shells and other sponges, and initially lack cloaca, although no osculum, and their exauli may be very short or very long; exowall imperforate except for equatorial ring of large, circular exopores at ends of spout-like exauli or sometimes merely strongly rimmed; at inner end of each exaulos is a hemispherical sieve of smaller circular pores (cribribulla) that bulges into chamber; inner surface of exowall may have anastomosing network of fibers applied to it, but no fibers are know from lumen of chamber itself; vesicles may be present in lumen; endowall pierced by small to large, circular endopores, often concentrated into two sieve-like rings, one near lower and one near upper end of chamber; these rings may bulge into chamber; when successive segments are in contact, interwall double, being two exowalls; cloaca of new branch arising through exowall; exauli of successive segments may occasionally join; long exauli of protocysts may invade other sponges; wall microstructure consists of small (20 to $60 \mu \mathrm{m})$, isodiametric spherulites; laminar, secondary layer of clinogonal (penicillate) structure may be present on inside of walls lining chamber; no spicules known" (Finks \& Rigby 2004b, p. 658).

\section{Girtyocoelia minima n. sp.}

Figures 3A, B

Diagnosis. - Small girtyocoeliid with chambers only 0.6-0.7 $\mathrm{mm}$ high and $1.9 \mathrm{~mm}$ in diameter, with axial spongocoel tube $0.7-0.8 \mathrm{~mm}$ in diameter and opening $0.4 \mathrm{~mm}$ in diameter; pores in chamber walls commonly $0.06-0.08 \mathrm{~mm}$ in diameter.

Description. - The holotype is a small, multichambered sponge fragment $5.3 \mathrm{~mm}$ high. It includes approximately 8 stacked chambers, 5 of which are clearly exposed in a verti- cal section, and 3 others exposed in the more or less continuous dermal surface (Fig. 3A). These chambers are 0.6-0.7 $\mathrm{mm}$ high, and have interwalls approximately $0.2 \mathrm{~mm}$ thick, with considerable variation in the coarsely silicified skeletal elements. These chambers are $1.9 \mathrm{~mm}$ in diameter around an axial spongocoel that has an outer diameter of $0.8 \mathrm{~mm}$ and a central tube approximately $0.4 \mathrm{~mm}$ in diameter (Fig. 3B).

Chamber exowalls are $0.08-0.14$ mm thick, with considerable variation and with only modest to faint impressions of pores that range $0.04-0.08 \mathrm{~mm}$ in diameter, with most $0.06-0.08 \mathrm{~mm}$ in diameter. These impressions are $0.04-0.10 \mathrm{~mm}$ apart, where best preserved in upper parts of the chambers. There are no prominent tubular exaules in any of the chamber walls, nor are interpores evident, which may be partially a result of the spinose-looking crystalline structure of the chamber walls, where small crystals up to $0.1 \mathrm{~mm}$ long are common and normal to the wall surfaces.

The base of the holotype (Fig. 3B) shows the interior of the basal-preserved chamber fragment, including the open central tube, the nodose or spinose, upper, chamber wall, and the coarsely preserved outer wall of the chamber.

Etymology. - Minima, Latin, smaller, in reference to the unusually small size of the sponge and its chambers.

Type specimen. - Holotype, USNM 480697, is the only known specimen of the species.

Occurrence. - The holotype was collected from Locality 2, from Late Ordovician rocks from the Livengood B-5 Quadrangle, east-central Alaska.

Discussion. - The single specimen, the holotype, is a small sponge, and it was early considered to be an immature near-basal part of a chambered sponge. However, because the chamber and spongocoel dimensions are essentially constant through the 5 chambers in the column, it is here considered to be part of an adult sponge. As such, it is one of the smallest known adult sponges of the genus Girtyocoelia.

\section{Genus Girtyocoeliana Rigby, Karl, Blodgett \& Baichtal, 2005}

Type species. - Girtyocoelia epiporata Rigby \& Potter, 1986, p. 39, fig. 8.1-8.4.

Diagnosis. - "Moniliform to branched stems of adnate, subspherical chambers that increase in size upward; exowalls imperforate except for large incurrent ostia at about midheight; chambers lack exaules; central tube prosipho- 
nate(?). Prominent rimmed to tubular interpores in irregular rings around central tube. Small expores in upper part of central tube in each chamber" (Rigby et al. 2005, p. 687).

\section{Girtyocoeliana epiporata (Rigby \& Potter, 1986) Figures 3C, D}

1986 Girtyocoelia epiporata Rigby \& Potter, p. 39, figs 8.1-9.4.

2005 Girtyocoeliana epiporata (Rigby \& Potter, 1986). Rigby, Karl, Blodgett \& Baichtal, pp. 867-868, fig. 3.1-3.4.

Diagnosis. - As for genus.

Description. - The most impressive specimen of the species, USNM 480698, is approximately $15 \mathrm{~mm}$ tall and consists of 5 diagonally stacked chambers of the middle to upper parts of the skeleton (Fig. 3C). These chambers are 6-8 $\mathrm{mm}$ in diameter and range $2.0-3.0$ to $4.5 \mathrm{~mm}$ high, with rounded walls. A short branch or part of a single chamber diverges from the lower chamber. That branch is $2.5 \times 4 \mathrm{~mm}$ in diameter and $2.0-3.8 \mathrm{~mm}$ tall from the exowall of the main lower chamber. The branch has a laterally flattened, central osculum $0.6 \times 2.6 \mathrm{~mm}$ across.

Exowalls are faintly nodular, with low nodes up to $0.7-1.0 \mathrm{~mm}$ in diameter, and with only obscurely preserved inhalant pores approximately $0.2 \mathrm{~mm}$ in diameter.

The uppermost chamber fragment exposes the central tubular spongocoel and the coarse interpores (Fig. 3D). The central spongocoel is $2.3 \mathrm{~mm}$ in diameter, with a wall $0.3-0.4 \mathrm{~mm}$ thick. The surrounding interwall in pierced by circular to angular interpores that are $0.2-0.4 \mathrm{~mm}$ across, and that are separated by vertical walls that are $0.2-0.5 \mathrm{~mm}$ thick, with thickest parts near the wall of the spongocoel and thinnest elements near the dermal walls of the chambers. This results in two or three irregular "rings" of such interpores. Similar interwall structure is less well preserved and exposed in the lower fragment and the interpores are faintly evident in the laterally flattened skeletal structure.

Material. - One moderately large fragment of the species, USNM 480698, is in the collection from Locality 2.

Occurrence. - Late Ordovician rocks, from Locality 2, Livengood B-5 Quadrangle, east-central Alaska.

Discussion. - Placement of this sponge in this genus is somewhat questionable because there are apparently several openings through each interwall, and most do not show as walled openings above the chamber interwalls.
Family Cliefdenellidae Webby, 1969

Diagnosis. - "Sphinctozoans with low, flat to convexupward chambers with imperforate walls; interwalls penetrated by continuous, subvertical, porous, pillarlike tubes; complex astrorhizae-like, clustered, excurrent, canal system separate from pillarlike incurrent system and occurring between thin, imperforate walls; skeletons of aspicular calcium carbonate" (Finks \& Rigby 2004b, p. 681).

\section{Genus Cliefdenella Webby, 1969}

Type species. - Cliefdenella etheridgei Webby, 1969, p. 655 .

Diagnosis. - "Sphinctozoan sponges composed of low, platelike, hollow chambers with imperforate interwalls pierced by porous, vertical, pillarlike tubes produced by downward deflection of interwall in retrosiphonate-like, incurrent, canal system; excurrent system of astrorhizal-like canals that converge laterally from chambers and curve vertically into clusters of subvertical, tubelike openings; vertical incurrent and excurrent tubes not interconnected; vesiculae may occur in early chambers, in vertical, porous, incurrent tubes, and in excurrent canals; interwalls may be three layered, with lower and upper, clear layers separated by a medial, dark layer; upper surface commonly denticulate" (Finks \& Rigby 2004b, p. 681).

Discussion. - Cliefdenella and Rigbyetia Webby \& Lin, 1988, are quite similar genera in terms of internal skeletal structures, but Cliefdenella is a low, broad sponge composed of low plate-like chambers and Rigbyetia is a more obconical to subcylindrical sponge (Finks \& Rigby 2004b, pp. 681, 683). The fragments included here are from a broad plate-like sponge that has overgrown other colonial calcareous specimens and seems most appropriately placed in Cliefdenella. In addition, it has remnants of cyst plates that fill between the laminae and the tubular pillars.

\section{Cliefdenella alaskaensis Stock, 1981}

Figures 3E, F

1981 Cliefdenella alaskaensis Stock, pp. 1000-1004, Pl. 1, figs $1-8$.

Diagnosis. - "Sheetlike laminae spaced $4.5-10.5$ per $5 \mathrm{~mm}$, $0.05-0.20 \mathrm{~mm}$ thick, separated by galleries $0.25-1.33 \mathrm{~mm}$ high. Long (up to $19.42 \mathrm{~mm}$ ) tube-pillars spaced 2.0-8.0 per $5 \mathrm{~mm}, 0.25-0.60 \mathrm{~mm}$ in diameter, $0.38-1.13 \mathrm{~mm}$ apart. 
Tube-pillar walls $0.05-0.11 \mathrm{~mm}$ thick. Cyst-plates in tube-pillars spaced $1.5-7.0$ per $\mathrm{mm}$. Up to 28 canals in astrorhizal columns" (Stock 1981, p. 1000).

Description. - The larger fragment, USNM 480699, is a horizontally layered specimen with prominent vertical tube-pillars connecting between layers (Fig. 3E). The fragment is approximately $18 \mathrm{~mm}$ long, $10 \mathrm{~mm}$ wide, and 4-5 mm thick. The sheet-like laminae or layers are gently arched and commonly $0.3-0.5 \mathrm{~mm}$ thick, but their details are not well preserved in the crystalline replacement. They are irregularly up to $0.8 \mathrm{~mm}$ apart, vertically. Some intervening horizontal canals have circular cross sections and range $0.25-0.5 \mathrm{~mm}$ in diameter. They appear irregularly oriented but are so uncommon and poorly preserved that their lateral patterns are not known. The vertical pillar-like tubes are hollow, with smooth interiors and with tips that may arch downward from where they intersect the transverse layers (Fig. 3E). They are irregularly separated, and range $0.3-0.9 \mathrm{~mm}$ apart (Fig. $3 \mathrm{~F}$ ). They are up to $0.4 \mathrm{~mm}$ in diameter, where circular, and $0.45 \times 1.1 \mathrm{~mm}$ across, where with an ovate transverse section. Their walls are 0.06-0.08 $\mathrm{mm}$ thick, although irregularly replaced with crystalline silica. Tube walls have hints of openings approximately $0.1 \mathrm{~mm}$ in diameter, but because the walls are so crystalline one can not be sure they are original pores.

Material. - One moderately large, figured, fragment of the species, USNM 480699, and a smaller, broken, unfigured one, USNM 480700, are from Locality 1, and are associated with mostly small unidentifiable skeletal fragments, and 4 sphinctozoan specimens with spheroidal stacked chambers.

Occurrence. - The two specimens of the species were collected from Locality 1, from a limestone unit from the White Mountain area, McGrath A-4 Quadrangle, westcentral Alaska.

Discussion. - The holotype and five paratypes of Cliefdenella alaskaensis Stock (1981, pp. 998-1005, pl. 1) were earlier collected from the Medfra D-2 Quadrangle from west-central Alaska. Classification of these sponges has been discussed above, in treatment of the genus.

Order Vaceletida Finks \& Rigby, 2004b

Family Colospongiidae Senowbari-Daryan, 1990

Diagnosis. - "Porate, thalamid sponges without a central canal or spongocoel and without filling structures; pores of segments unbranched or with only dichotomous branches; basal skeleton primarily aragonitic" (Finks \& Rigby 2004b, p. 697).
Subfamily Colospongiidae Senowbari-Daryan, 1990

Diagnosis. - "Chambers or segments in linear, moniliform arrangements" (Finks \& Rigby 2004b, p. 697).

\section{Genus Pseudoimperatoria Senowbari-Daryan \& Rigby, 1988}

Type species. - Pseudoimperatoria mega (Rigby \& Potter, 1986), p. 23.

Diagnosis. - "Cylindrical, branching sponge, occasionally anastomosing, composed of superposed, conical chambers, each flaring to a sharp, upper edge with flat, upper surface; no cloaca; exopores small, widely spaced, or two sizes; interwall sievelike with large, subangular to submeandriform interpores separated by narrow trabeculae; no internal structures in chambers; microstructure not known; no spicules known" (Finks \& Rigby 2004b, pp. 699, 700).

\section{Pseudoimperatoria minima (Rigby \& Potter, 1986)}

Figures 3G-I

1986 Imperatoria minima Rigby \& Potter, pp. 26, 27, fig. 8.6, 8.10, 8.15, 8.16.

1988 Pseudoimperatoria minima (Rigby \& Potter, 1986).Senowbari-Daryan \& Rigby, p. 195.

Diagnosis. - "Small catenulate almost tube-like Imperatoria (edit, Pseudoimperatoria) in linear to branching series. Chambers approximately $1 \mathrm{~mm}$ in diameter, and range 1-5 mm long, with upward flaring, weakly sculptured rims. Chambers become tube-like with flaring margins at the immediate base and top, to produce a moderately sharply annular profile. Interwalls generally finely perforate, pores $0.1 \mathrm{~mm}$ or smaller, although occasional larger circular openings up to $0.20 \mathrm{~mm}$ in diameter occur on some moderate flaring branches" (Rigby \& Potter 1986, p. 26).

Description. - One of the better preserved specimens of the small-chambered species, USNM 480701, is a curved columnar form, $14 \mathrm{~mm}$ tall, composed of small turriculate chambers that increase in dimensions upwards (Fig. 3G). It includes 10 moderately well-defined chambers, each of which flares upward to a more or less pronounced rim. Nature of chamber interwalls is not evident in this specimen.

Basal chambers are smallest, 0.7-0.8 mm tall, and expand upward from bases approximately $0.7 \mathrm{~mm}$ in diameter, to flare to upper rims $1.0-1.1 \mathrm{~mm}$ in diameter. The lowest chamber fragment has a central opening of $0.3 \mathrm{~mm}$ that is surrounded by walls $0.2 \mathrm{~mm}$ thick. 


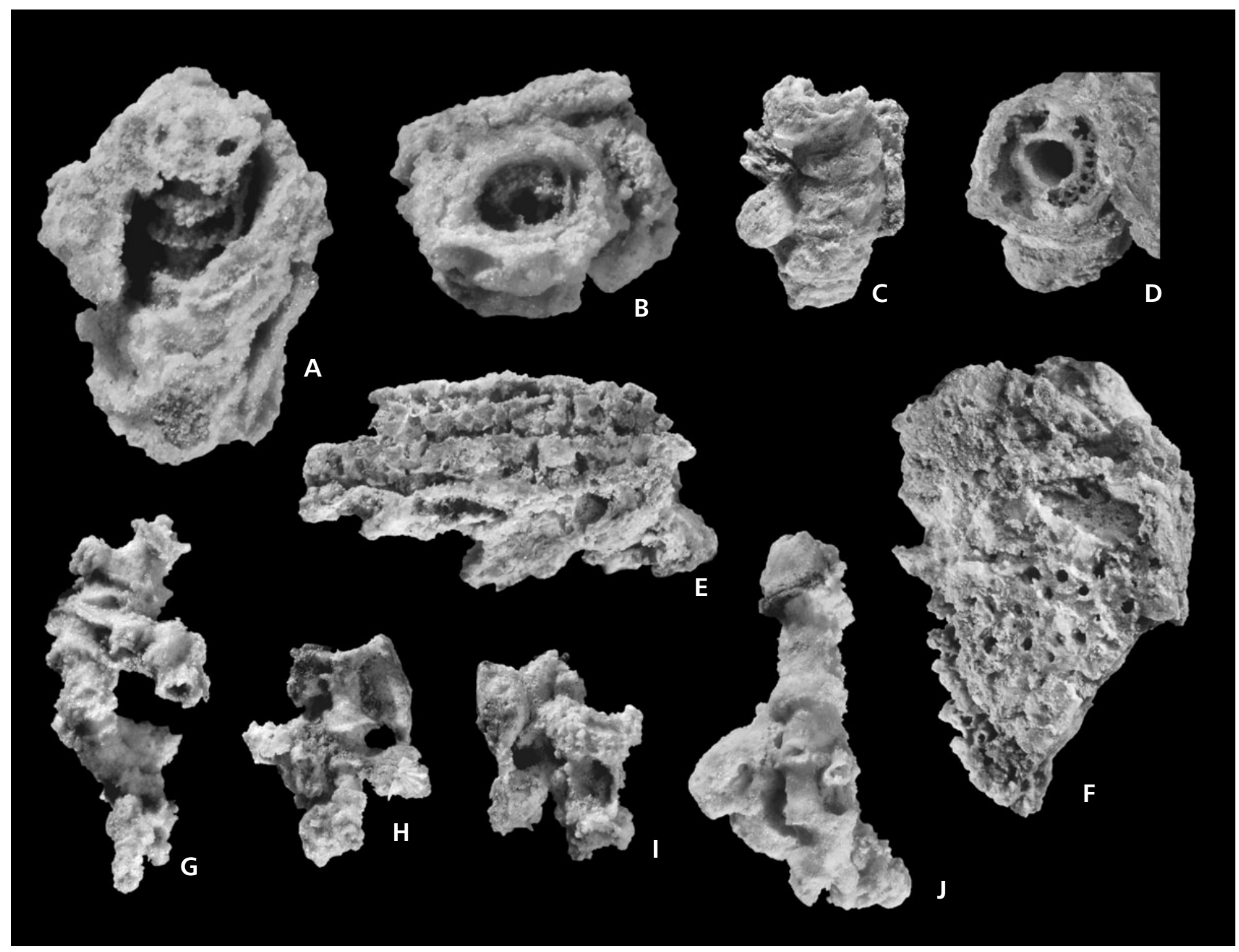

Figure 3. Photographic figures of species of Girtyocoelia, Girtyocoeliana, Cliefdenella and Pseudoimperatoria. • A, B - Girtyocoelia minima n. sp., holotype, USNM 480697, Locality 2. A - side view of small holotype with four exposed chamber interiors around the retrosiphonate central spongocoel tube, with nodose interwalls in the interior, all surrounded by matrix on the exterior, $\times 4$. B - view up into interior of the basal-preserved chamber fragment, showing the open central tube, the nodose or spinose upper chamber wall, and the coarsely preserved outer wall of the sponge, $\times 8$. - C, D - Girtyocoeliana epiporata (Rigby \& Potter, 1986), figured specimen, USNM 480698, Locality 2. C - side view of multichambered, moniliform, stem fragment, with obscure gray inhalant ostia in coarsely silicified exowall, and attached chamber on the left side, $\times 2$. D - view of upper end of stem fragment showing central tubular spongocoel and rings of coarse interpores, some of which have vertical walls, in the surrounding interwall, all surrounded by a coarsely silicified exowall that is partially buried in silicified matrix, $\times 2$. $\bullet$ E, F - Cliefdenella alaskaensis Stock, 1981, figured specimen, USNM 480699, Locality 1. E - side view of the fragment showing irregularly preserved horizontal laminae and intervening, partially filled, galleries, and tiny fragments of the vertical tube-pillars, $\times 4$. F - view from above of upper horizontal sheet-like lamina that is pierced by pores of tube-pillars, which also interconnect and extend down into the skeleton and separate underling horizontal laminae and help produce intervening horizontal galleries, $\times 3$. - G-I - Pseudoimperatoria minima (Rigby \& Potter, 1986), figured specimens, USNM 480701 and 480702, Locality 3. G - side view of fragment of stem composed of superposed small, turriculate, chambers, each of which generally increases in diameter and height upward in the stem, and each also flairs near the top and the bottom to produce sharp annular profiles to the chambers; a small adherent Corymbospongia fragment branches off near the summit, USNM 480701, $\times 4$. H, I - small near-basal fragment of a monolinear stem of the species and encrusting or overgrowing associated species, USNM 480702. $\mathrm{H}$ - front view of cluster with exposed view of $P$. minima stem, whose chambers also generally increase in size upwards and have the same flaring shapes as in the larger specimen of the species, above, and are partially covered with fragments of associated Corymbospongia species, $\times 4$. I - back view of the same cluster, coated principally with associated specimens of nodular Corymbospongia, $\times 4 \cdot \bullet \mathrm{J}-$ Pseudoimperatoria media Rigby \& Potter, 1986 , figured specimen, USNM 480703, Locality 3 , side view of stem with moderately large chambers that have turriculate to annular columnar forms; small inhalant ostia are locally preserved in walls of the lower chambers, USNM 480704, $\times 4$.

Dermal chamber dimensions increase upward to $1.2-1.3 \mathrm{~mm}$ tall and $1.2-1.4 \mathrm{~mm}$ in diameter, at narrow midchamber heights, with diameters of $1.7-1.9 \mathrm{~mm}$ at the flaring rims and chamber junctions. Upper chambers are up to $1.5 \mathrm{~mm}$ high, $2.2 \mathrm{~mm}$ in lower diameter, and expand up- ward to distinct flaring rims up to $3.3 \mathrm{~mm}$ in diameter and $0.2-0.4 \mathrm{~mm}$ thick. Chamber walls below the rim are approximately $0.2 \mathrm{~mm}$ thick, but thicken upward to form rims up to $0.4 \mathrm{~mm}$ thick or wide, that overhang lower parts of chambers up to $0.3-0.4 \mathrm{~mm}$, where prominent. 
The uppermost flaring rim is approximately $2.6 \mathrm{~mm}$ in diameter and is pierced by a central opening $0.9 \times 1.2 \mathrm{~mm}$ in diameter, surrounded by walls $0.2 \mathrm{~mm}$ thick (Fig. 3G).

Another near-basal stem fragment, USNM 480702, is $8 \mathrm{~mm}$ tall and composed of upward enlarging chambers (Fig. 3H). They range from a complete lower one $0.08 \mathrm{~mm}$ in diameter and $1.4 \mathrm{~mm}$ tall, with a flaring upper rim $1.3 \mathrm{~mm}$ in diameter and $0.2-0.3 \mathrm{~mm}$ thick, up to an upper one 1.5 in diameter and $1.8 \mathrm{~mm}$ tall, with a flaring rim $2.5 \mathrm{~mm}$ in diameter and $0.3 \mathrm{~mm}$ thick. Skeletal pores are poorly defined in these siliceous replacements, but a few inhalant pores, $0.06-0.08 \mathrm{~mm}$ in diameter, are preserved in some lower chamber walls. Their spacing is not evident in the nodular irregular skeletal replacement. This sponge, like some of the others of the species, has adnate isolated chambers of Corymbospongia, which here form a small compound cluster (Fig. 3H, I).

Material. - Four specimens of the species, including the figured specimens USNM 480701 and 480702, are in the studied collections.

Occurrence. - Four specimens of the species were recovered from Locality 3, Yx-51-70, from the Sheep Mountain Quadrangle, approximately $0.63 \mathrm{mi}$. $(1.0 \mathrm{~km})$ east of the Alaska-Canada border, in Yukon Territory.

Discussion. - The specimens here classified as Pseudoimperatoria minima (Rigby \& Potter, 1986) are moderately well preserved fragments of the species and are characterized by their aligned, small turriculate chambers. They do have the rhythmic flaring rims characteristic of the genus. Rigby \& Potter (1986, p. 27) suggested the possibility that such small forms may be juveniles of another species of the genus. However, as they noted, the consistent dimensions of these sponges indicate that they are "mature parts of small specimens rather than juvenile stages of larger species".

\section{Pseudoimperatoria media (Rigby \& Potter, 1986) Figure 3J}

1988 Imperatoria media Rigby \& Potter, 1986, pp. 24-26, fig. 9.1-9.4; Rigby, Potter \& Blodgett, pp. 737, 738, fig. 5.1, 5.2.

1988 Pseudoimperatoria media (Rigby \& Potter, 1986). Senowbari-Daryan \& Rigby, p. 195.

Diagnosis. - "Middle-sized Imperatoria media (edit, Pseudoimperatoria) with chambers $2-3 \mathrm{~mm}$ high, rarely to $9 \mathrm{~mm}$ high; with annular rather than abrupt cup-like growth form. Interwall pores and elements small and delicate. Pores $0.10-0.25 \mathrm{~mm}$ in diameter with skeletal elements between them of essentially the same size" (Rigby \& Potter 1986, pp. 24-26).

Description. - Two fragmental silicified specimens of the species are in the collection. The better one, USNM 480703, has been etched free, and is a well exposed, turriculate to annular columnar form that is approximately $13.5 \mathrm{~mm}$ tall (Fig. 3J). It includes parts of 7 chambers that range $1.0-2.6 \mathrm{~mm}$ in diameter in the narrowed middle part of each chamber, and 3.0-4.6 in diameter in the upper, radially flared, thickened rims. Most chambers are slightly elliptical, like the lower one that is $1.9 \times 2.8 \mathrm{~mm}$ at the base, $1.6 \times 1.9 \mathrm{~mm}$ at the narrowed midheight, and $3.3 \times 3.8 \mathrm{~mm}$ at its flared rim.

The incomplete basal chamber of the column is essentially circular, with an outer wall diameter of $1.9 \mathrm{~mm}$, and diagonally broken exowalls 0.2 to $0.5 \mathrm{~mm}$ thick around a central opening $1.6 \mathrm{~mm}$ in diameter. Impressions in the poorly preserved dermal surface of the exowall suggest common inhalant pores approximately $0.04 \mathrm{~mm}$ in diameter. A few larger pores, to $0.14 \mathrm{~mm}$ in diameter, also occur in the dermal surface and may represent exhalant canals in the lower part of the sponge.

Basal parts of each chamber are commonly inset 0.3-0.5 $\mathrm{mm}$ from rims of the underlying chambers, taper to midheight, before expanding slightly, and then flaring into the upper rims. Chambers range from 2.1 to $2.6 \mathrm{~mm}$ high, except for the chamber at the sharp bend in the column that is $2.3 \mathrm{~mm}$ high on one side, but wedges out at the other side, where its flared rim is in contact with that of the underlying chamber.

The uppermost chamber fragment is $1.7 \times 2.4 \mathrm{~mm}$ across and has an ovoid chamber opening $1.0 \times 1.4 \mathrm{~mm}$ in diameter. The exowall there is $0.15 \mathrm{~mm}$ thick on the narrow sides, but thickens up to $0.3 \mathrm{~mm}$ thick into the elongate ends.

Chambers are separated internally by porous interwalls. The basal interwall of the uppermost chamber fragment is one of the few preserved and it has several pores that are $0.04-0.06 \mathrm{~mm}$ in diameter and that are spaced about the same distance apart.

The other silicified fragment of the species, USNM 480704, includes four adnate chambers and a columnar segment, which has parts of 4 chambers and is $10 \mathrm{~mm}$ tall. The more or less complete lower middle chamber of that columnar segment is $3.0 \mathrm{~mm}$ tall, has a midheight narrow diameter of $1.7 \times 1.9 \mathrm{~mm}$, and an upper flared rim $2.7 \times$ $3.2 \mathrm{~mm}$ in diameter. That flared rim is $0.3-0.4 \mathrm{~mm}$ thick, and the chamber wall at midheight is $0.2 \mathrm{~mm}$ thick. The lower incomplete middle chamber is $3.0 \mathrm{~mm}$ tall, and $3.9 \mathrm{~mm}$ in diameter at the flaring rim. Both chambers have midheight walls $0.2 \mathrm{~mm}$ thick and walls $0.5-0.6 \mathrm{~mm}$ thick near the upper rim.

The flared rim of that lower fragment is ovate and $2.6 \times$ $3.3 \mathrm{~mm}$ in diameter and $0.4-0.5 \mathrm{~mm}$ thick. 
The lowermost part of the columnar fragment is of the upper part of a chamber that is $2.0 \mathrm{~mm}$ tall, with a flared upper rim $2.8 \times 3.3$. The central part of the chamber is ovate and $1.5 \times 2.0 \mathrm{~mm}$ in diameter, with walls $0.14-0.18 \mathrm{~mm}$ thick. A fragmental interwall is perforated by a few interpores that are $0.04-0.04 \mathrm{~mm}$ in diameter.

Material. - Two fragmental specimens, USNM 480703, the figured specimen, and 480704, are in the collection from Locality 3, Yukon Territory. The short columnar specimen (Fig. 3I) is partially overgrown with four adnate chambers of exaulos-bearing Corymbospongia betella Rigby, Potter \& Blodgett, 1988, and a fragment of a finely (?)spiculed, massive unidentified (?)sponge.

Occurrence. - The two specimens were recovered with other sponges from Locality 3, (Yx-51-70), from the Sheep Mountain Quadrangle, approximately $0.63 \mathrm{mi}$. (1.0 km) east of the Alaska-Canada border, in Yukon Territory, Canada.

Discussion. - The sponges included here in the species Pseudoimperatoria media are distinctly larger chambered than those included in P. minima Rigby \& Potter, 1986, documented above, although both have the turriculate chambers characteristic of the genus. On the other hand, the sponges treated here are smaller chambered than the large-chambered Pseudoimperatoria mega Rigby \& Blodgett (1986, pp. 23, 24), the type species of the genus. They are also better organized into columnar structures or linear series of chambers than those sponges included in Pseudoimperatoria irregularis Rigby \& Potter (1986, pp. 27, 28).

Subfamily Corymbospongiinae Senowbari-Daryan, 1990

Diagnosis. - "Glomerate to stratiform arrangement of chambers" (Finks \& Rigby 2004b, p. 701).

\section{Genus Corymbospongia Rigby \& Potter, 1986}

Type species. - Corymbospongia adnata Rigby \& Potter, 1986.

Diagnosis. - "Clusters of spheroidal to ellipsoidal chambers, possibly encrusting; each chamber bearing long exaulos often arising from a mamelon-like protuberance; exauli of cluster tend to face same direction (possibly upward); chamber walls perforated by small, circular pores that bear lips on inner wall of chamber; adjacent chambers may communicate by these pores but not by exauli; no internal structures except possibly vesicles; microstructure not known; no spicules known" (Finks \& Rigby 2004b, pp. 701, 702).
Corymbospongia betella Rigby, Potter \& Blodgett, 1988 Figures 4A, B

1988 Corymbospongia betella Rigby, Potter \& Blodgett, pp. 739, 740, fig. 5.5, 5.6, 5.11, 5.12.

Diagnosis. - "Clusters of isolated chambers that may be adnate, glomerated, or moderately distant; where adnate, mutually accommodating, beet-shaped or turbonate to pyriform chambers mainly 4-5 mm in maximum diameter, each with elongate imperforate exaulos from broad conical mound approximately $2 \mathrm{~mm}$ in diameter, from which exaulos tube narrows abruptly to $1.0-1.5 \mathrm{~mm}$ in diameter and perforated by a simple pore; exaulos walls may be obscurely perforate; endowalls coarsely perforate with pores as short tubes or with distinct rims" (Rigby et al. 1988, p. 739).

Description. - The single specimen of the species in the current collection, USNM 480705, is a fragment $9 \mathrm{~mm}$ tall, which includes one complete chamber and fragments of the overlying and underlying chambers (Fig. 4A). The barrel-shaped chamber is $5.2 \mathrm{~mm}$ tall, $5.0 \mathrm{~mm}$ in maximum diameter at midheight, and $3 \mathrm{~mm}$ in diameter at indented contacts with the overlying and underlying chambers. These fragments are each about $2 \mathrm{~mm}$ high and $3 \mathrm{~mm}$ in diameter at their broken ends.

An exaulos tube is present on the side of the lower and major chambers. That on the major chamber has an obconical base $2.5 \mathrm{~mm}$ in diameter that tapers abruptly to $1.4 \mathrm{~mm}$ in diameter at the broken tip of the tube, which is $2.5 \mathrm{~mm}$ long. The exaulos fragment on the wall of the lower chamber is $2.0-2.5 \mathrm{~mm}$ long, has a base $2.0 \mathrm{~mm}$ in diameter and a broken tip $1.0 \mathrm{~mm}$ in diameter. The tubes are filled with matrix but suggest canals $0.6-0.7 \mathrm{~mm}$ in diameter at the broken tips. Openings for exaules in the dermal layer, where the tubes are not developed, are approximately $0.4 \mathrm{~mm}$ in diameter.

Exopores are irregularly preserved in the dermal layer and are not aligned. Larger such pores are approximately $0.20 \mathrm{~mm}$ in diameter and spaced $0.2-0.5 \mathrm{~mm}$ apart. Smaller pores are $0.08-0.12 \mathrm{~mm}$ in diameter and are spaced $0.1-0.2 \mathrm{~mm}$ apart. They occur in a fine skeletal mesh where openings $0.10-0.152 \mathrm{~mm}$ are separated by fibers $0.01-0.02 \mathrm{~mm}$ in diameter.

An upward-arched interwall is preserved at the base of the major chamber (Fig. 4B). That wall is $0.15 \mathrm{~mm}$ thick in the interior, but is up to $0.25 \mathrm{~mm}$ thick near the base of the exaulos. Interpores there are $0.12-0.18 \mathrm{~mm}$ in diameter and are surrounded by low, ridge-like, walls $0.10-0.12 \mathrm{~mm}$ high and wide. These pores are $0.3-0.5 \mathrm{~mm}$ apart.

Material. - A single fragment, figured specimen USNM 480705 , is the only specimen of the species in the current collection. 
Occurrence. - A single known fragment of the species was recovered from Locality 3, Yx-51-70, from approximately 0.63 mi. $(1.0 \mathrm{~km})$ east of the Alaska-Canada border, in $\mathrm{Yu}-$ kon Territory, Canada.

Discussion. - Dimensions of the chambers preserved here are like those of $C$. betella, and the rimmed or walled short tubes of the interpores, like those in the type material (Rigby et al. 1988, p. 739), suggest this species classification of the sponge fragment.

\section{Corymbospongia mica Rigby \& Potter, 1986 Figures $4 \mathrm{C}-\mathrm{F}$}

1986 Corymbospongia mica Rigby \& Potter, pp. 29-31, fig. $10.8,10.9$.

Diagnosis. - "General form as for genus but with small chambers $1.0-1.5 \mathrm{~mm}$ in diameter and exaulos tubes 0.4-0.6 mm in diameter" (Rigby \& Potter 1986, p. 28).

Description. - One of the better preserved clusters of the species, USNM 480706, includes approximately 20 small chambers in the irregularly adnate and moderately coarsely silicified specimen (Fig. 4F). Individual spheroidal chambers range $1.5-1.8 \mathrm{~mm}$ in diameter and are associated with less common ovoid ones that are to $1.5 \mathrm{~mm}$ in diameter and 1.8-1.9 mm tall. Chambers walls are perforate and have inhalant pores $0.14-0.18 \mathrm{~mm}$ in diameter.

One end, or side, of each chamber commonly has an obconical exaulos base that is $0.7-0.8 \mathrm{~mm}$ in diameter and which tapers in diameter to $0.4-0.5 \mathrm{~mm}$ in approximately $0.5 \mathrm{~mm}$. There they form bases to the outer cylindrical exaulos tubes, which continue at $0.4-0.5 \mathrm{~mm}$ in diameter and range up to $0.5-0.8 \mathrm{~mm}$ long to their broken or complete tip. Their central tubular openings, or exaules canals, are approximately $0.2 \mathrm{~mm}$ in diameter, or wide, where slightly ovate.

Another cluster, USNM 480707, includes 16 adnate chambers that are commonly $1.5 \mathrm{~mm}$ in diameter (Fig. 4D), but with a large one that is $2.2 \mathrm{~mm}$ tall and $1.2 \mathrm{~mm}$ in diameter. These chambers have walls perforated by inhalant ostia that are $0.14-0.16 \mathrm{~mm}$ in diameter and spaced about the same distance apart. Most of these pores are partially filled in the siliceous preservation. Each chamber commonly has a single exaulos with a flaring base, like in the cluster above, with outer tubular ends that are $0.5 \mathrm{~mm}$ in diameter, in which the former canals are now filled with silica.

Three other small clusters of silicified spheroidal chambers are in the collection, including figured specimens USNM 480708 and 480709 (Fig. 4C, E). They form columns $5.0-5.5 \mathrm{~mm}$ tall. Most of these chambers have clearly defined exaulos tubes $0.3-0.4 \mathrm{~mm}$ in basal diameters and some taper to $0.2 \mathrm{~mm}$ at their incomplete, broken tips in their microcrystalline preservations. Some of these tips have impressions of exaulos openings approximately $0.15 \mathrm{~mm}$ in diameter.

Material. - Four figured specimens, USNM 480706480709, and an additional 7 specimens of the species were collected from Locality 3.

Occurrence. - The studied specimens were recovered, with other sponges, from Locality 3, Yx-51-70, approximately $0.63 \mathrm{mi}$. (1.0 km) east of the Alaska-Canada border, in Yukon Territory, Canada.

Discussion. - Rigby \& Potter (1986, p. 31) questioned whether the holotype of $C$. mica represented a new species, or only the juvenile phase of a larger species of the genus. The several sponges included here clearly represent a small-chambered species and, as Rigby \& Potter noted (1986, p. 31), "there appears to be no transition forms between those with very small chambers and those with larger chambers".

\section{Corymbospongia $($ ?) perforata Rigby \& Potter, 1986} Figures 4G-I

1986 Corymbospongia(?) perforata Rigby \& Potter, pp. 31, 32, fig. 10.7.

Diagnosis. - "Intermediate-sized, subspherical to oval chambers adnate to arranged in irregularly annular series, with porous exaulos generally 1 per chamber. Exaules approximately $1 \mathrm{~mm}$ in diameter and up to $9 \mathrm{~mm}$ long" (Rigby \& Potter 1986, p. 31).

Description. - Specimens of the species range from moderately large clusters of chambers to fragments with only a few chambers (Fig. 4G). One of the better specimens, USNM 480710, is a cluster of 8 chambers that are adnate and somewhat modified because they are attached to one another. Chambers are generally spheroidal and 2.3-3.2 mm in diameter or high, but some are up to $3.5 \mathrm{~mm}$ tall, and others are also ovoid and $2.5-3.2 \mathrm{~mm}$ across. Inhalant pores in the chamber walls are $0.10-0.20 \mathrm{~mm}$ in diameter and occur about that far apart between coarser pores that are $0.15-0.20 \mathrm{~mm}$ in diameter and are somewhat farther apart. These pores are perforations into a fine skeletal mesh, where small pores $0.02-0.04 \mathrm{~mm}$ in diameter are separated or surrounded by siliceous fibers of the same dimensions, or locally up to approximately $0.08 \mathrm{~mm}$ in diameter.

Each chamber has a prominent exaulos (Fig. 4G) that has an attached obconical base, approximately $1.5 \mathrm{~mm}$ in 


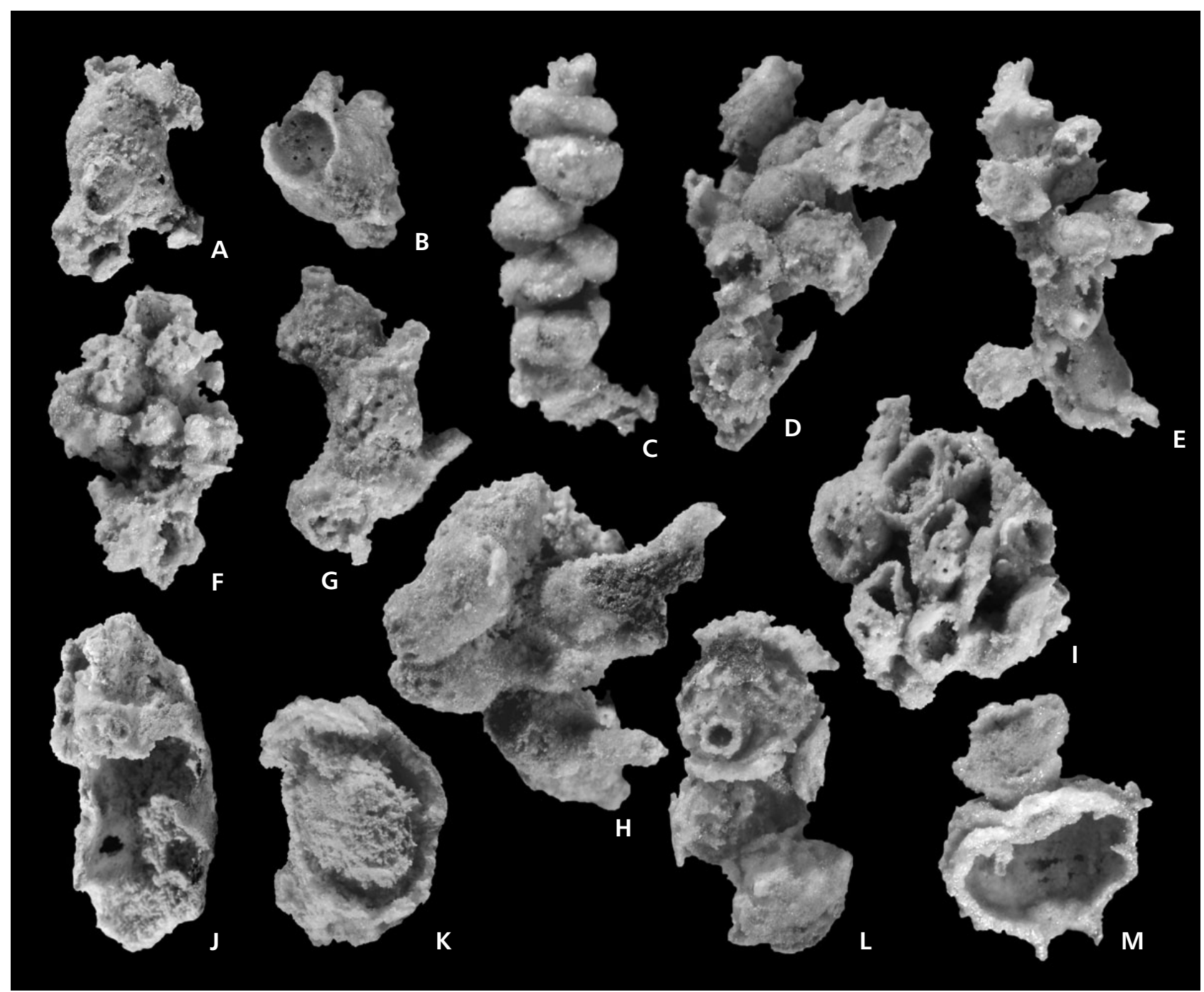

Figure 4. Photographic figures of specimens of species of Corymbospongia and Nucha. • A, B - Corymbospongia betella Rigby, Potter \& Blodgett, 1988, fragment of the species, figured specimen, USNM 480705, Locality 3. A - side view of the specimen with one large complete chamber, minor indented fragments of walls of associated chambers, and segments of elongate exaulos tubes; irregularly preserved large exopores are evident in the outer wall and somewhat smaller interpores in the upper part of the front-facing chamber impression, $\times 4$. B - view up into the upper interwall of a lower chamber, where some walled interpores are preserved; and some exopores are evident in the upper outer wall $\times 4$. $\bullet \mathrm{C}-\mathrm{F}-$ Corymbospongia mica Rigby \& Potter, 1986 , small clusters of chambers as figured specimens, USNM 480706-480709, Locality 3. C - one of the better preserved, but smallest specimens, is a linear series of adnate chambers that total $5.5 \mathrm{~mm}$ tall and each has a few, preserved, small inhalant ostia approximately $0.15 \mathrm{~mm}$ in diameter; each chamber also has a single exaulos tube fragment that is approximately $0.5 \mathrm{~mm}$ in diameter, USNM 480708, $\times 10$. D - somewhat linear-branching cluster about $10 \mathrm{~mm}$ tall of adnate chambers, with a larger chamber near the top, where some inhalant ostia are preserved; most chambers have basal parts of exaulos tubes, USNM $480707, \times 5$. -E - moderate, branched, linear cluster of elongate chambers, some with exposed, long, exaulos tubes and some with inhalant ostia apparent in their silicified walls, USNM $480709, \times 5 \cdot \bullet \mathrm{F}$ - compact cluster of approximately 20 small chambers, each with a short exaulos tube and some with open inhalant ostia in the silicified preservation, USNM 480706, × 5. • G-I - Corymbospongia(?) perforata Rigby \& Potter, 1986, USNM 480710, 535901, and 535902, Locality 3 , small figured clusters of larger chambers. $\mathrm{G}$ - small linear cluster of three complete chambers, each with a prominent exaulos tube, and an additional lower fragment; inhalant pores are prominent in the chamber walls, USNM 480710, $\times 5$. $\mathrm{H}$ - cluster of eight irregularly adnate chambers, some of which have distinct inhalant pores and others with prominent exaulos tubes, USNM 5359000, $\times 5$. I - small cluster of somewhat aligned chambers, some of which have aligned exaulos tubes and open inhalant pores in their chamber walls; two others have interpores between fragments of adnate chambers, USNM $535901, \times 5$. - J, K - Corymbospongia amplia Rigby, Karl, Blodgett \& Baichtal, 2005, fragments of large figured sponge, USNM 535902, Locality 2. J - side view of stem fragment where indistinct, possible, coarse pores show in dermal surface of upper part, and upward arcuate interwalls faintly show between three lower chambers on the interior of the outer wall, USNM 535902a. K - view down onto the domed, perforate, interwall of a lower fragment of the sponge, where open interpores are preserved between small silica spines; an incomplete chamber exowall partially rings the fragment, USNM 535902b, $\times 4$. $\bullet$ L, M - Nucha naucum? Pickett \& Jell, 1983, USNM 505903 and 505904, Locality 3. L - moniliform series of three spheroidal, nodose chambers, and a lower chamber fragment; small inhalant pores show between the nodes, particularly in the lower chamber, and large, rimmed, exaules perforate the chamber walls at midheight, with one exaulos most prominent in the lower chamber, USNM 535903, ×4. M - fragment of two silicified chambers of a demosponge, where segments of a discontinuous axial spongocoel tube are developed between the two chambers and in the lower wall of the lower chamber, USNM $535904, \times 5$. 
diameter, which abruptly narrows to approximately $1.0 \mathrm{~mm}$ in diameter and then gently narrows toward the preserved tip. Most exaules are broken near their bases, but some are up to approximately $3 \mathrm{~mm}$ long. These exaules have tubular canals approximately $0.3 \mathrm{~mm}$ in diameter and walls $0.3 \mathrm{~mm}$ thick in their inner or middle parts. One larger exaulos is $0.9-1.0 \mathrm{~mm}$ in diameter, with a canal $0.3-0.4 \mathrm{~mm}$ in diameter.

A somewhat similar specimen, USNM 535900, is $6 \times$ $8.8 \mathrm{~mm}$ across and includes 10 chambers and fragments in a tight, adnate cluster (Fig. 4H), which is fairly coarsely silicified. Chambers are 2.0-2.7 $\mathrm{mm}$ in diameter and have walls $0.1-0.4 \mathrm{~mm}$ thick of poorly preserved micromesh, with pores or mesh openings $0.02-0.04 \mathrm{~mm}$ in diameter. Interpores between adnate chamber walls are $0.10-0.12 \mathrm{~mm}$ in diameter and $0.2-0.4 \mathrm{~mm}$ apart. Some other pores in single chamber walls are up to $0.2 \mathrm{~mm}$ in diameter and may have been inhalant openings. Exaules are not well preserved, but fragments up to $3 \mathrm{~mm}$ long do occur and have bases 1.1-1.3 in diameter. They taper to broken tips $0.7-1.0$ in diameter, with axial canals up to $0.2-0.3 \mathrm{~mm}$ in diameter.

The other figured specimen, USNM 535901 (Fig. 4I), has similar chamber and exaulos dimensions, as do the other fragments in the collection.

Material. - Fragments of the species in the studied collection includes three figured specimens, USNM 480710, 535900 and 535901, and an additional 38 fragments of various sizes and range of numbers of chambers.

Occurrence. - The studied specimens were recovered with other sponges from Locality 3, Yx-51-70, approximately $0.63 \mathrm{mi}$. (1.0 km) east of the Alaska-Canada border, in Yukon Territory, Canada.

Discussion. - Specimens of the species in the collection are similar to the Ordovician holotype described from California (Rigby \& Potter 1986, p. 31), but do show some variability in chamber size, pore dimensions, and exaulos development.

\section{?Corymbospongia amplia Rigby, Karl, Blodgett \& Baichtal, 2005}

Figures 4J, K

2005 Corymbospongia amplia Rigby, Karl, Blodgett \& Baichtal, pp. 865-867, fig. 4.1, 4.2.

Diagnosis. - "Large chambers to $15.0 \mathrm{~mm}$ in diameter, with less common exaulos tubes to $2.5 \mathrm{~mm}$ in diameter and to over $25 \mathrm{~mm}$ long; exaules lack sieve plates; chambers interconnected by interpores where in mutual contact, exo- walls with pores $0.10-0.15 \mathrm{~mm}$ in diameter between low nodes" (Rigby et al. 2005, p. 865).

Description. - A single columnar fragment, USNM 535902, now broken into four parts, possibly represents the species in the collection (Fig. 4J, K). Combined parts produce a stem fragment $26 \mathrm{~mm}$ tall, which is composed of chambers mainly 3-5 mm tall, although the lower fragment appears to be of a chamber $7 \mathrm{~mm}$ tall. These chambers range $7.8-8.2 \mathrm{~mm}$ in diameter and are separated by shallow indentations at their junctions. Both gastral and dermal surfaces of the exowalls are low nodose. These exowalls are commonly $0.4-0.5 \mathrm{~mm}$ thick, and preserved with irregular crystalline silicification. Only a few indistinct, possible pores are preserved in the exowalls, and they are irregularly up to $0.10-0.14 \mathrm{~mm}$ in diameter, with considerable variation.

Upward arcuate interwalls are preserved between chambers in the lower part of the sponge (Fig. 4J). They are $0.5 \mathrm{~mm}$ thick, with common small spines that are up to $0.2 \mathrm{~mm}$ long and appear to thicken the interwall. Interpores in the interwalls (Fig. 4K) are $0.14-0.16 \mathrm{~mm}$ in diameter, where circular, or $0.14 \times 0.20 \mathrm{~mm}$ across where ovoid. They are irregularly up to $0.6 \mathrm{~mm}$ apart.

Material. - Only parts of the single, large chambered specimen, USNM 535902, are considered to possibly represent the species in the collection.

Occurrence. - The figured specimen fragments were recovered from Late Ordovician beds from Locality 2, on the Livengood B-5 Quadrangle, in east-central Alaska.

Discussion. - The specimen is classified in the genus and species with some question because of its fragmental nature. However, the prominent development of porous interwalls between the chambers, the sizes of the chambers, and their stacked columnar arrangement suggest its taxonomic placement here.

Class Heteractinida de Laubenfels, 1955

Order Octactinellida Hinde, 1887

Family Nuchidae Pickett, 2002

Diagnosis. - "Small, globular to obconical heteractinids with a coarsely perforate, largely aspiculate wall, and distal oscule with raised, imperforate rim" (Finks \& Rigby 2004a, p. 577).

Discussion. - Previously reported fossils of the family have been documented only from Cambrian rocks of Australia (Pickett \& Jell 1983, p. 90; Kruse, 1987, p. 543 and 545). These Canadian sponges are the first specimens of the genus reported from North America, and are the first reported Ordovician forms too. 


\section{Genus Nucha Pickett \& Jell, 1983}

Type species. - Nucha naucum Pickett \& Jell, 1983, p. 90.

Diagnosis. - "Ambisiphonate sebargasiids with subspherical chambers with narrow junctions and closely spaced pores of non-uniform size" (Pickett \& Jell 1983, p. 91).

\section{Nucha naucum? Pickett \& Jell, 1983}

Figure 4L, M

2004a Nucha naucum Pickett \& Jell, 1983, pp. 90, 91, fig. 4A-L; Finks \& Rigby, pp. 577, 578, fig. 380-3a, b.

Diagnosis. - "Hollow, subspherical chambers with prominent rimmed oscula at both upper and lower poles, wall perforated by closely spaced pores of various sizes; distinct isolated-appearing chambers probably joined into linear series at poles" (Finks \& Rigby 2004a, pp. 577, 578).

Description. - The larger of the better preserved and figured specimens of the species, USNM 535903, consists of three stacked chambers and fragments of the overlying and underlying chambers (Fig. 4L). The entire specimen is $12 \mathrm{~mm}$ tall, with complete chambers ranging, from bottom up, from $2.8 \mathrm{~mm}$ tall and $4.5 \times 5.0 \mathrm{~mm}$ in diameter, $3.5 \mathrm{~mm}$ tall and $4.2 \times 4.7 \mathrm{~mm}$ in diameter, and then to $3.5 \mathrm{~mm}$ tall and $5.0 \times 5.1 \mathrm{~mm}$ in diameter. The basal chamber has an exposed tubular osculum $1.2 \mathrm{~mm}$ in diameter, with a central tube $0.4-0.5 \mathrm{~mm}$ in diameter and that extend approximately $0.4 \mathrm{~mm}$ down into the basal fragment. The only other partially exposed central tubule is in the base of the uppermost chamber fragment, where the tubule is capped by an expanded transverse screen that is approximately $2.5 \mathrm{~mm}$ in diameter. That tubule is approximately $1 \mathrm{~mm}$ in diameter, where exposed.

Each of the chambers is marked by a moderate- to large-size lateral pore in its dermal surface. That pore in the upper chamber is approximately $1.6 \mathrm{~mm}$ in diameter and is bounded by a tubular wall, $0.5 \mathrm{~mm}$ tall and $0.3-0.4 \mathrm{~mm}$ thick, around a pore $0.8-0.9 \mathrm{~mm}$ in diameter. This is the largest such lateral opening in the specimen. The middle chamber has a lateral tubule near the top of the chamber that is $1.2 \mathrm{~mm}$ in diameter and $0.6 \mathrm{~mm}$ tall, with a central pore $0.3-0.4 \mathrm{~mm}$ in diameter. The lower chamber has a similar lateral tubule $1.0 \mathrm{~mm}$ in diameter, with a central pore $0.4 \mathrm{~mm}$ in diameter. That tubule is $1.0 \mathrm{~mm}$ tall. Pickett \& Jell (1983, p. 91) suggested that the chambers might have been joined at tubular poles.

Skeletal nodules occur on dermal layers of these Yukon specimens. Largest well-defined conical nodes occur on the lower chamber and range up to $0.4-0.6 \mathrm{~mm}$ high, above bases $0.7-1.1 \mathrm{~mm}$ in diameter. Smaller nodes are irregu- larly preserved and range up to $0.3 \mathrm{~mm}$ in diameter between pores in the dermal layer on all the chambers. Such pores commonly range $0.16-0.18 \mathrm{~mm}$ in diameter, although some to $0.20 \mathrm{~mm}$ in diameter also occur locally. These pores are bordered by irregular polyactine rays of "spicules" that are up to $0.02 \mathrm{~mm}$ in diameter.

The smaller of the two specimens, USNM 535904, consists of a vertical section through an upper chamber, with an overlying tubular osculum, and a partial underlying lower chamber, with an upper interconnecting tubular osculum (Fig. 4M). The upper chamber is $5.8 \mathrm{~mm}$ in diameter and $4.5 \mathrm{~mm}$ high, with walls approximately $0.3-0.4 \mathrm{~mm}$ thick, and they appear thickest around the base of the imperforate oscular tube. That upper tubular osculum is $1.1 \mathrm{~mm}$ tall and $2.0 \mathrm{~mm}$ in diameter, with a central open osculum $1.3 \mathrm{~mm}$ in diameter. That tube wall is to $0.5 \mathrm{~mm}$ thick, at the base, and thins to $0.3 \mathrm{~mm}$ thick at the summit. These tubular walls are not continuous, but both are limited to a short distance above and below the upper chamber walls.

The lower tubular osculum has a lower diameter of 1.5, with a central tube $0.9 \mathrm{~mm}$ in diameter. That central tube is capped by a screen, approximately $2.5 \mathrm{~mm}$ in diameter, which has multiple pores, like those seen in the gastral surface of the chamber wall, when viewed from below, but there are no large pores evident in the upper "layer" of the screen.

The dermal surface of the chamber wall is silicified and shows irregular, partially filled, pores and nodes in the outer part. The pores are like those clearly developed in the porous, fine reticulate meshwork in the gastral surface of the wall, which are approximately $0.10 \mathrm{~mm}$ in diameter and occur irregularly side by side. There are no large pores in the outer wall like those present in the larger specimen, noted above.

A third possible specimen of the species, USNM 535905 , consists of two upper chambers and some attached basal exaules that are $0.7-0.8 \mathrm{~mm}$ in diameter and $2-3 \mathrm{~mm}$ long. The dermal surfaces of the upper chambers are marked with nodes and filled pores(?), like in the figured specimens described above. The two stacked chambers are 4.3-4.6 $\mathrm{mm}$ in diameter and 3.5-3.7 $\mathrm{mm}$ high. Both have lateral dermal tubular pores. The most evident side pore in the upper chamber is $0.7 \mathrm{~mm}$ long, with a central tube $0.3 \mathrm{~mm}$ in diameter and with walls $0.2 \mathrm{~mm}$ thick. A similar tubular pore in the lower chamber is approximately $1 \mathrm{~mm}$ long, $1.5 \mathrm{~mm}$ in diameter, with a flared base $2.3 \mathrm{~mm}$ in diameter and walls $0.3 \mathrm{~mm}$ thick, where exposed at the tube tip. It has an axial opening $0.6 \mathrm{~mm}$ in diameter at the fractured summit, with a small interpore opening. Features of the gastral surface are not exposed.

Material. - Two figured specimens of the species, USNM 535903 and 535904, and two additional specimens, inclu- 
ding reference specimen USNM 535905, are in the collection from Locality 3.

Occurrence. - The four specimens of the species were collected from Locality 3, Yx-51-70, approximately $0.63 \mathrm{mi}$. $(1.0 \mathrm{~km})$ east of the Alaska-Canada border, in Yukon Territory, Canada.

Discussion. - As noted in discussion of the genus, above, these are the first specimens of the genus and species reported from North America. Tubules such as those present in these Canadian specimens were not reported in the type specimens of Nucha naucum Pickett \& Jell, 1983. However, none of the type chamber specimens of that species were in stacked series, even though Pickett \& Jell (1983, p. 91) suggested that the stacked series might have been joined by tubular poles.

\section{Discussion}

The small Girtyocoelia minima n. sp., from Locality 2 in east-central Alaska, was initially considered to be a juvenile sponge because of its small size. However, middle and upper chambers of the small specimen have relatively uniform dimensions, and we interpret them as regular chambers of a small adult. This sponge is the oldest and smallest documented species of the genus.

Corymbospongia amplia Rigby, Karl, Blodgett \& Baichtal, 2005, is the only species of the genus reported from the Alaskan accreted terranes and it occurs only at Locality 2 . However, the genus is represented by several species the autochthonous terrane of Laurentia. These species are differentiated by variations in pore and chamber sizes and exaulos developments and they include $C$. betella Rigby, Potter \& Blodgett, 1988; C. mica and C. perforata(?) Rigby \& Potter, 1986. Of these, C. perforata(?) is the most abundant in this collection and is represented by 41 fragments. Approximately 20 specimens of $C$. betella, including five type specimens, were earlier collected from the White Mountain area of west-central Alaska (Rigby et al. 1988, p. 740).

Cliefdenella Webby, 1969, and Rigbyetia Webby \& Lin, 1988, have somewhat similar internal skeletal structures of vertical incurrent and excurrent tubes and vesiculae, but their growth forms are quite different. Cliefdenella, as shown here (Fig. 3E, F), is a low broad sponge with plate-like chambers separated by imperforate or sheet-like interwalls pierced by numerous, pillar-like vertical tubes. Rigbyetia is a more obconical to subcylindrical sponge with low, ring-like, chambers with sheet-like, imperforate laminate interwalls (Finks \& Rigby 2004b, p. 683, fig. 453d), which are also locally downwardly inflexed into coarser vertical to subvertical incurrent tubes. These genera also occur in Ordovician rocks of Australia (Finks \& Rigby 2004b, pp. 681, 683).

\section{Conclusions}

Sponges in the present collections represent fossils from both the autochthonous North American terrane of Laurentia, from Locality 3 in the Jones Ridge area of the Alaska-Yukon border region, and from accreted terranes, from Locality 1, in the White Mountain of west-central Alaska, and from Locality 2 in the White Mountains area of east-central Alaska (Figs 1,2). The diverse fauna from Locality 3 was recovered from an etched cobble and includes several species of Corymbospongia and Pseudoimperatoria that had been earlier reported from Ordovician rocks of the Klamath Mountains of northern California (Rigby \& Potter 1986). Such occurrences enforce the conclusion that both the Alaskan and Oregon localities are in autochthonous Laurentian terranes.

On the other hand, the less diverse collection from a limestone debris flow at Locality 1, of only Cliefdenella alaskensis Stock, 1981, and unidentifiable sphinctozoan fragments. The collection from a conglomerate pebble at Locality 2, consists of only a single specimen of the new species Girtyocoeliana minima, three fragments of Girtyocoeliana epiporata (Rigby \& Potter, 1986), and one fragment of Corymbospongia amplia Rigby, Karl, Blodgett \& Baichtal, 2005. The sponges from both of these localities are considered to be from accreted Siberian terranes.

The heteractinid sponge Nucha naucum(?) Pickett \& Jell, 1983, from Locality 3, is reported here from North America for the first time. Previously, this genus and species was only known from New South Wales, Australia.

\section{Acknowledgments}

We appreciate the support of colleagues in the Department of Geological Sciences at Brigham Young University. Photographic images of the fossil sponges in the figures were partially prepared by Nicolle Anderson, and Elise Robertson assisted in typing revisions of the manuscript, while both were students in the department at Brigham Young University and, at that time, employees of the Museum of Earth Science. We also express appreciation to Andrzej Pisera, Joachim Reitner, and an unidentified colleague for critical reviews of the manuscript.

\section{References}

BlodgetT, R.B \& Boucot, A.J. 1999. Late Early Devonian (late Emsian) eospiriferinid brachiopods from Shellabarger Pass, Talkeetna C-6 Quadrangle, south-central Alaska and their biogeographic importance; further evidence for a Sibe- 
rian origin of the Farewell and allied Alaskan accreted terranes. Senckenbergiana Lethaea 72(1), 209-221.

BLODGETT, R.B., ROHR, D.M. \& BOUCOT, A.J. 2002. Paleozoic links among some Alaskan accreted terranes and Siberia based on megafossils, 273-291. In Miller, E.L., GRANTZ, A. \& KLEMPERER, S.L. (eds) Tectonic evolution of the Bering Shelf-Chucki Sea-Arctic Margin and adjacent landmasses. Geological Society of America Special Paper 360. DOI 10.1130/0-8137-2360-4.273

Churkin, M., JR., Foster, H.L., Chapman, R.M. \& Weber, F.R. 1982. Terranes and suture zones in east central Alaska. Journal of Geophysical Research 87(5), 3718-3730. DOI 10.1029/JB087iB05p03718

Cossman, M. 1909. Rectifications de nomenclature. Revue Critique Paléozoologie 13, 67.

DeCKer, J., Bergman, S.C., Blodgett, R.B., Box, S.E., Bundtzen, T.K., Clough, J.G., COONRAD, W.L., GILBERT, W., Miller, M.L., Murphy, J.M., Robinson, M.S. \& WALLACE, W.K. 1944. Chapter 9, Geology of southwestern Alaska, 285-310. In PlafKer, G. \& BERG, H.C. (eds) The Geology of Alaska. The Geology of North America (DNAG), Volume $G-1$.

Dumoulin, J.A., HARRis, A.G., GagieV, M., BRAdLEy, D.C. \& REPETSKI, J.E. 2002. Lithostratigraphic, conodont and other faunal links between lower Paleozoic strata in northern and central Alaska and northeastern Russia, 291-312. In MILLER, E.L., GRANTZ, A. \& KLEMPERER, S.L. (eds) Tectonic evolution of the Bering Shelf-Chukshi Sea-Arctic Margin and adjacent landmasses. Geological Society of America Special Paper 360. DOI 10.1130/0-8137-2360-4.291

FINKS, R.M. \& RIGBY, J.K. 2004a. Heteractinida, E557-E583. In Kaesler, R.L. (ed.) Treatise on Invertebrate Paleontology, Part E, Porifera (revised). Volume 3. Geological Society of America, Denver \& The University of Kansas Press, Lawrence.

FINKS, R.M. \& RigBY, J.K. 2004b. Hypercalcified sponges, 585-758. In KAESLER, R.L. (ed.) Treatise on Invertebrate Paleontology, Part E, Porifera (revised). Volume 3. Geological Society of America, Denver \& The University of Kansas Press, Lawrence.

GILBERT, W.G. 1981. Preliminary geologic map and geochemical data, Cheeneetnuk River area, Alaska. Alaska Division of Geological and Geophysical Surveys, Open-file report 153, 10 pp.

GIRTY, G.H. 1908. On some new and old species of Carboniferous fossils. Proceedings of the U.S. National Museum 34, 281-303.

HINDE, G.J. 1887. A monograph of the British fossil sponges, part 1. Palaeontological Society Memoir, London, 1-92.

HoOPER, J.N.A. \& VAN SOEST, R.V.M. 2002. Systema Porifera: A guide to the classification of sponges. Volume 1, Introductions and Demospongiae, 1-1099; Volume 2, 1103-1707. Kluwer Academic/Plenum Publishers, New York.

KRUSE, P.D. 1987. Further Australian Cambrian sphinctozoans. Geological Magazine 124, 543-553.

Laubenfels, M.W. De 1955. Porifera, E21-E112. In MoORE, R.C. (ed.) Treatise on Invertebrate Paleontology. Part E,
Archaeocyatha and Porifera. Geological Society of America \& University of Kansas Press, New York \& Lawrence, Kansas.

LÉVI, C.L. 1953. Sur un nouvelle classification des Démosponges. Comptes rendus hebdomadaires des séances de l'Académie des Sciences, Série D 236, 835-855.

PATTON, W.W. 1978. Juxtaposed continental and oceanic-island arc terranes of the Medfra quadrangle, west-central Alaska, B38-B39. In JoHnson, K.M. (ed.) The United States Geological Survey in Alaska - Accomplishments during 1977. U.S. Geological Survey Circular 772-B.

PICKETT, J. 2002. Order Heteractinida Hinde, 1877, 1121-1139. In HoOper, J.N.A. \& VAN SoEST, R.W.M. (eds) Systema Porifera: A guide to the classification of sponges. Kluwer Academic/Plenum Publishers, New York.

PICKeTt, J. \& Jell, P.A. 1983. Middle Cambrian Sphinctozoa (Porifera) from New South Wales. Memoir Association of Australasian Palaeontologists 1, 85-92.

Potter, A.W., Blodgett, R.B. \& Rohr, D.M. 1988. Paleobiogeographic relations and paleogeographic significance of Late Ordovician brachiopods of Alaska. Geological Society of America Abstracts with Programs 20(7), 339.

PotTer, A.W., Gilbert, W.G., ORMiston, A.R. \& Blodgett, R.B. 1980. Middle and Upper Ordovician brachiopods from Alaska and northern California and their paleobiogeographic implications. Geological Society of America Abstracts with Programs 12(3), 147.

REITNER, J. \& KEUPP, H. Eds. 1991. Fossils and recent sponges. 595 pp. Springer-Verlag, Berlin.

RigBY, J.K. \& BlodgetT, R.B. 1983. Early Middle Devonian sponges from the McGrath quadrangle of west-central Alaska. Journal of Paleontology 57(4), 773-786.

Rigby, J.K. \& PotTer, A.W. 1986. Ordovician sphinctozoan sponges from the eastern Klamath Mountains, northern California. Paleontological Society Memoir 20, Journal of Paleontology 60, supplement, 1-47.

Rigby, J.K., PotTeR, A.W. \& BlodgetT, R.B. 1988. Ordovician sphinctozoan sponges of Alaska and Yukon Territory. Journal of Paleontology 62, 731-746.

Rigby, J.K., KARL, S.M., BlodgetT, R.B. \& BAichtal, J.E. 2005. Ordovician "sphinctozoan" sponges from Prince of Wales Island, southeastern Alaska. Journal of Paleontology, 79(5), 862-870.

DOI: 10.1666/0022-3360(2005)079[0862:OSSFPO]2.0.CO;2

RigBY, J.K., NiteCKI, M.H., SOJA, C.M. \& BlodgetT, R.B. 1994. Silurian aphrosalpingid sphinctozoans from Alaska and Russia. Acta Palaeontologica Polonica 39, 341-391.

Rigby, J.K., Rohr, D.M., BlodgetT, R.B. \& BRoOKs, B.B. 2008. Silurian sponges and some associated fossils from the Heceta Limestone, Prince of Wales Island, southeastern Alaska. Journal of Paleontology 80(1), 91-101.

DOI 10.1666/06-047.1

Rigby, J.K. \& SenOwbari-Daryan, B. 1999. Upper Permian inozoid, demospongid, and hexactinellid sponges from Djebel Tebaga, Tunisia. The University of Kansas Paleontological Contributions (new series) 7, 1-130. 
ROSS, R.J. JR. \& DUTRO, J.T. JR. 1966. Silicified Ordovician brachiopods from east-central Alaska. Smithsonian Miscellaneous Collections 149(7), 1-22.

SENOWBARI-DARYAN, B. 1990. Die systematische Stellung der thalamiden Schwämme und ihrer Bedeutung in der Erdgeschichte. Münchner Geowissenschaftliche Abhandlungen (Reihe A, Geologie und Paläontologie) 21, 1-325.

SENOWBARI-DARYAN, B. \& RigbY, J.K. 1988. Upper Permian segmented sponges from Djebel Tebaga, Tunisia. Facies 19, 171-250. DOI 10.1007/BF02536825

SOLLAS, W.J. 1875. Sponges. Encyclopaedia Britannica $\left(9^{\text {th }}\right.$ edition), p. 427-446. Adam \& Charles Black, Edinburgh.

Stоск, C.W. 1981. Cliefdenella alaskaensis n. sp. (Stromatoporoidea) from the Middle/Upper Ordovician of central Alaska. Journal of Paleontology 55(5), 998-1005.
VERRILL, A.E. 1907. Porifera of the Bermuda Islands. Transactions of the Academy of Arts and Sciences 12, 330-344.

WEBBY, B.D. 1969. Ordovician stromatoporoids from New South Wales. Palaeontology 12, 637-662.

WeBBY, B.D. \& LIN BAYOU 1988. Upper Ordovician cliefdenellids (Porifera: Sphinctozoa) from China. Geological Magazine 125(2), 149-159.

WEBER, F.R., BLODGETT, R.B., HARRIS, A.G. \& DUTRO, J.T. JR. 1994. Paleontology of the Livengood quadrangle, Alaska. U.S. Geological Survey Open-file Report 94-215, 24 pp., 1 sheet, scale $1: 250,000$.

Weber, F.R., WheEler, K.L., Rinehart, C.D., Chapman, R.M. \& BLODGETT, R.B. 1992. Geologic map of the Livengood quadrangle, Alaska. U.S. Geological Survey, Open-file Report 92-562, 20 pp., 1 sheet, scale $1: 250,000$. 